\title{
Philosophical and scientific interaction between Vladimir Vernadsky and Pavel Florensky*
}

\author{
L. Naldoniová \\ University of Ostrava, \\ 7, Dvořákova, Ostrava, 701 03, Czech Republic
}

For citation: Naldoniová L. Philosophical and scientific interaction between Vladimir Vernadsky and Pavel Florensky. Vestnik of Saint Petersburg University. Philosophy and Conflict Studies, 2020, vol. 36, issue 4, pp. 645-656. https://doi.org/10.21638/spbu17.2020.404

The article focuses on the philosophical and scientific dialogue between Vladimir Vernadsky and Pavel Florensky in the context of Russian philosophy. Florensky formulated his philosophy in the book The Pillar and Ground of the Truth, making a great impact on Vernadsky. The two philosophers exchanged their thoughts through letters. During the time of his imprisonment, Florensky wrote letters on scientific topics to his son Kirill, who worked with Vernadsky. Thus, Kirill Florensky became the point of contact between the two thinkers. The present article aims to show the complementarity between Vernadsky's and Florensky's work with a particular emphasis on their conception of noosphere-pneumatosphere connected with Plato's methaphysics, which Florensky interpreted as the world of the Truth or absolute reality. Through investigating Vernadsky's and Florensky's letters and diaries and comparing their conceptions of noosphere and pneumatosphere, as well as their interpretation of reality in their writings, it is possible to determine influences of the concepts important for Russian religious philosophers, such as a tendency towards wholeness and intuition. The first part of the article examines Vernadsky in relation to Russian idealists, the second part of the article is focused on the relationship between Vernadsky and Florensky, and the third on the concepts of noosphere, pneumatosphere, and the concept of reality (living being) - absolute reality (Truth). Through these three steps, the complementarity of Vernadsky's and Florensky's interpretations are illustrated. Their interpretations are not contradictory because while Vernadsky dealt with Earth's reality and its evolution, and Florensky focused on the metaphysical world, both were interested in the evolution of the biosphere-noosphere/pneumatosphere through the activity of man. The article is the first study in English focused on the scientific and religious-philosophical interaction between Vernadsky and Florensky.

Keywords: Vladimir Vernadsky, Pavel Florensky, noosphere, pneumatosphere, Russian philosophy, asymmetry, dissymetry, living matter, reality, intuitive knowledge, Truth, wholeness.

Although Russia underwent a political earthquake during the oppressive Soviet period that deprived many prominent personalities of their freedom, Vladimir Vernadsky (1863-1945) and Pavel Florensky (1882-1937) managed to continue their activities. Evidence of their scientific and philosophical interaction can be found mainly in their correspondence and diaries. Here, Florensky's son Kirill became a key figure. Kirill was not only Vernadsky's most important follower, he also assisted Florensky's and Vernadsky's

* This article is published as the result of research funded by the Faculty of Arts, University of Ostrava, project SGS03/FF/2019-2020 "Bílá místa dějin a současnosti filozofie: Osobnosti a témata na okraji kánonu".

(c) Санкт-Петербургский государственный университет, 2020 
scientific interaction during the time of Florensky's imprisonment by passing his father's letters to Vernadsky, with whom he later worked with in the same laboratory.

The Russian naturalist and mineralogist Vladimir Vernadsky is universally recognized as a scientist, but his philosophical thoughts are less known in the Western world ${ }^{1}$. Vernadsky is considered to be the founder of the new science of biogeochemistry, and his elaboration of the concept of the biosphere is even used today. Vernadsky's lesser known concept of the noosphere is connected with the Anthropocene debate, which began in $2000^{2}$. Some scholars saw Vernadsky's noosphere as one of the precursors to the notion of the Anthropocene [2].

Both of the aforementioned concepts were admired by the Orthodox priest and scientist Pavel Florensky, who was one of the leading Russian religious philosophers active during the Silver Age. Florensky admired Vernadsky's approach to wholeness, which was typical of Russian religious philosophical thought. Vernadsky's idea of noosphere was very similar to what Florensky referred to as "pneumatosphere", a term he used in a letter to Vernadsky.

Unlike Florensky, who is recognized to have been both a religious philosopher and a scientist, Vernadsky is famous only as a scientist despite his interaction with Russian idealists and religious philosophers.

\section{Vernadsky and philosophy}

The first full-length English-language biography of Vernadsky is the book Science and Russian Culture in an Age of Revolutions. V.I. Vernadsky and His Scientific School, 18631945 (1990) written by Kendall E. Bailes, however as emphasised by Rosenthal, Bailes "ignores Vernadsky's religious-philosophical views" [3, p. 27]. Bailes did, nevertheless, admit that Vernadsky was interested in philosophy and leaned towards some kind of mysticism: "[Vernadsky] was widely read in both science and philosophy $<\ldots>$. He had also long had a mystical bent which he generally suppressed in his published work but which comes out in his unpublished correspondence and notebooks and even occasionally in print" $[4$, p. 122].

Vernadsky's spirituality was recognized by G. M. Young ${ }^{3}$, who put him among the Russian scientific cosmists discussed in the book The Russian Cosmists. The Esoteric Futur-

1 Today there are many western scientists taking an interest in Vernadsky's work. For instance, in the article "Geochemistry of natural waters - The Legacy of V.I. Vernadsky" (2012), Edmunds and Bogush focus on Vernadsky's book The History of Natural Waters, which still has not been translated into English. They write that "there are several reasons for his lack of renown in the west, but mainly because his most important work The Biosphere was only fully translated into English in 1997". Edmunds and Bogush are convinced that The History of Natural Waters is as important as The Biosphere [1, p. 1871].

2 The discussion about the precursors of the Anthropocene is still ongoing. In the article "Was the Anthropocene anticipated?", Clive Hamilton and Jacques Grinevald argue that "there were no precursors to the notion of the Anthropocene, and that there could not have been because the concept, put forward in the year 2000, is an outgrowth of the recent interdisciplinary understanding of the Earth as an evolving planet inaugurated in the 1980s by the Geosphere-Biosphere Programme and Earth system science. Earlier scientists who commented on 'the age of man' did so in terms of human impact on the environment or 'the face of the Earth', not the Earth system" [2].

${ }^{3}$ In Young's opinion, "Vernadsky was not religious in a conventional sense, but he was a deeply spiritual thinker, well read in the literature of the world's religions, and in Eastern and Western philosophy" [5, p.157]. 
ism of Nikolai Fedorov and his Followers. The problem is that Russian cosmism is difficult to define because it is "a highly controversial and oxymoronic blend of activist speculation, futuristic traditionalism, religious science, exoteric esoterism, utopian pragmatism, idealistic materialism - higher magic partnered to higher mathematics" [5, p.3]. In the book Faith and Science in Russian Religious Thought (2019), T. Obolevitch pointed out that Vernadsky shared with other cosmists "the view of the harmony of the universe expressed in the common chemical nature of all being. He recognized the phenomenon of life, the presence in the cosmos of 'living matter'...' [6, p. 152].

Bailes saw Vernadsky as one of the first scientists concerned with the role living matter' played in geochemical cycles and how it differed from inert matter [4, p. 122]. Vernadsky was convinced that the forms of living matter evolved and were not replicable, but Bailes was unable to determine whether his conviction came from the field of science or philosophy [4, p. 122]. The concept of "living matter" instead of "life" was introduced by Vernadsky into science. He believed that the term "life" comprehended philosophy, folklore, religion, and art $[7]^{4}$.

Vernadsky's concept of the noosphere is at the intersection of science based on empirical experiments and intuitive knowledge important for the platonically oriented Russian religious philosophers. The noosphere is the next stage in the evolution of the biosphere. While "it is essentially Vernadsky's concept of the biosphere, developed about fifty years after Suess wrote, that we accept today", the idea of the noosphere is closer to philosophical speculations than to empirical science: "the noosphere is neither pseudo-science nor new age nirvana, but rather a 'vision of the possible' based on the combination of physical parameters and human potential." Contrary to the term biosphere, which is now clearly specified by scientists, noosphere, although used in various contexts, remains scarcely defined $[8, \mathrm{p} .1]$.

In the article "Some words about the Noosphere" written in 1943, Vernadsky wrote that "the noosphere is a new geological phenomenon on our planet. In it, for the first time, man becomes a large-scale geological force. He can, and must, rebuild the province of his life by his work and thought, rebuild it radically in comparison with the past" [7, p. 20].

In the same article, Vernadsky raised the question of how thought could change material processes if it was not a form of energy, but this question has not been resolved yet. Vernadsky showed the empirical consequences of the noosphere, but he did not understand why it happened. Quoting Goethe, he recognized the limits of science: "in science we only can know how something occurred, but we cannot know why it occurred" [7, p. 20]. The question "why" is part of the field of philosophy, and Vernadsky's interests were not limited only to the scientific questions, but included philosophical and religious topics, as we know from his correspondence with Florensky.

Vernadsky admired Florensky, who was one of the most important of Vladimir Solovyov's followers, but Florensky was not the only Russian religious philosopher who interacted with Vernadsky. In 1901, Vernadsky became a member of the Psychological Society, and although most of its members were idealists, "realist" Vernadsky established

4 'Instead of the concept of 'life', I introduced that of 'living matter', which now seems to be firmly established in science. 'Living matter' is the totality of living organisms. It is but a scientific empirical generalization of empirically indisputable facts known to all, observable easily and with precision. The concept of 'life' always steps outside the boundaries of the concept of 'living matter'; it enters the realm of philosophy, folklore, religion, and the arts. All that is left outside the notion of 'living matter" [7, p. 17]. 
friendly relations with Pavel Novgorodtsev and Sergei Trubetskoi. The jurist-philosopher Novgorodtsev (1866-1924) and religious philosopher Trubetskoi (1862-1905), also Solovyov's follower, were both professors at the University of Moscow ${ }^{5}$. As a well-known professor of jurisprudence, Novgorodtsev became Vernadsky's close colleague at Moscow University and together with other friends they founded the liberal Kadet party [10, p. 136]. As a philosopher, Novgorotsev is seen as the most prominent follower of Kantianism within the Society [9, p. 281]. Prince Trubetskoi was a member of the Psychological Society from 1887 and his "importance in the growth of Russian idealism from the last decade of the nineteenth century was second only to that of Solovyov." Florensky studied philosophy with Trubetskoi at Moscow University, which he entered in the fall of 1899. Vernadsky had already taught at the same university from 1890 [9, p. 288].

Vernadsky and Trubetskoi began to participate in the organization of new higher education and society and in December 1904 they both "published articles calling on Russian professors to end their traditional passivity and organize themselves to push for reforms, both in higher education and in society at large" [4, p.97]. They were active at Moscow University, where in 1905 Prince Trubetskoi became a rector, albeit for a short time - he died soon after his election. Vernadsky was then elected assistant rector to his successor, professor Alexander Manuilov. During his activity in the Psychological Society, Vernadsky published the article "On the Scientific Worldview" $(1902)^{6}$ in the Society's journal Voprosy filosofii i psikhologii, where he wrote: “...the development of science undoubtedly evokes... the extraordinary extension of the boundaries of philosophical and religious consciousness of the human spirit" [6, p. 164]. Nemeth pointed out that "the paper displayed Vernadskij's extensive knowledge of the history of science that later would lead to his correspondence with the Belgian-American founder of the history of science as a discipline, George Sarton (1884-1956)" [9, p. 288]. In the article "Sarton and Vernadsky" (1984), Mikulinsky drew attention to the fact that "it has usually escaped attention that V.I. Vernadsky was also active as a historian of science" and that "Vernadsky considered the profession of history of science to be as worthy of pursuit as any other field of science, and after the late nineteenth century it became one of his professional occupations, alongside his research into mineralogy, geochemistry, and biogeochemistry" [12, p.56].

\section{Vernadsky and Florensky}

During the period of Vernadsky's activity in the Psychological Society, Florensky studied at the Faculty of Physics and Mathematics at Moscow University, in the Department of Higher Mathematics (1900-1904) [13, p. 184]. Vernadsky began to teach mineralogy and crystallography at the Moscow University in January of 1891 and later Florensky attended his lectures. Florensky was particularly impressed by Vernadsky's lectures on

${ }^{5}$ In Nemeth's words, Vernadsky gave a commemorative address, 'The Characteristics of Count S.N. Trubeckoj's Worldview', at Moscow University in 1908, which was published in the journal Russkaja Mysl' [Russian Thought]. Arguably indicative of his general attitude toward philosophical reflections on science, however, is his diary entry from December 1890: "It is surprising how 'philosophical' thinking, lagging behind scientific data due to inadequate scientific education, chiefly in the natural and mathematical sciences, often leads to comical statements" [9, p. 288].

6 The essay "O nauchnom mirovozzrenii" [On the Scientific Worldview] originally served as an introduction to the course of the history of natural science, which Vernadsky held at the beginning of 1900s at the Moscow University [11, p. 573]. 
geology and science in general, but his faith was most important and the main goal of his philosophy was to unify faith with science. This was also the main point of distinction between him and Vernadsky, who wanted science to remain separate from philosophy and religion. The question is whether Vernadsky's intention corresponds to his goal because the noosphere is a mixture of science and philosophical speculations about the rule of intelligence in changing the material world.

In the late 1920s and the 1930s, until his death in 1945, Vernadsky helped the children of persecuted people. Florensky's son Kirill (1915-1982) was among the children assisted, since Florensky was arrested in 1933. Kirill admired Vernadsky's work and later became his most important follower and the Soviet Union's leading geochemist and planetologist. During his imprisonment, Florensky wrote letters to his relatives and children, in which we also find references to Vernadsky, especially in the letters to Kirill.

In his letter from 13 April 1935, Florensky wrote that he would like his sons Vasja and Kirill to learn as much as possible from Vernadsky because he thought learning from great personalities, such as Vernadsky, was more useful than studying books [14, p. 209].

Florensky's admiration for Vernadsky partly stems from their common inclination to wholeness; in a letter to his wife Anna dated 21 June 1935, Florensky confessed that Vernadsky was the only person with whom he could discuss natural-philosophical topics freely because "all the others do not comprehend the world as a whole and only know particulars" [1, p. 248].

The idea of wholeness is one of the main topics of Russian religious philosophy. In the book The Pillar and Ground of the Truth, Florensky describes Truth as "something so total that it contains everything and therefore something that its name expresses only by convention, partially, symbolically" [15, p. 14].

It was during his journey from Simferopol to St. Peterburg in 1921 that Vernadsky read the above-mentioned book. He began reading on 27 February and finished on 4 March, being interested particularly in the Divine Sophia. On this subject, Vernadsky wrote in his Diary:

4.III. 1921. < ..> Last night, I had a big conversation with P. P. Kudryavtsev ${ }^{7}$ about St. Sophia in connection with Florensky, whom I finished reading today. Very interesting. As if a new creative work of religion is going on: Mother of God. Now St. Sophia is not an angel, not a man, the creation of God, not God. It is surprising that Florensky cast aside all Gnosticism, Kudryavtsev believes that the sophianists (V. Solovyov, Florensky, Bulgakov, E. Trubetskoy and others) are a new trend [16, p. 25].

Even though this letter illustrates that Vernadsky was familiar with the topics of Russian sophiology, the philosophical and theological problem which connects Vernadsky to Florensky is likely the idea of the line of separation between reality or living beings, and inert matter (in the case of Vernadsky) or absolute being called the Truth by Florensky. Silvano Tagliagambe dedicated a whole chapter of his book Come leggere Florenskij [How to read Florensky] to the problem of the line which separates two worlds, this world and the world of the Truth described by Florensky in The Pillar and Ground of the Truth

7 Petr Pavlovich Kudryavtsev (1868-1940) was a professor at the Department of History and Ancient Philosophy, Taurida University, in the period between 1919 and 1921. In 1921, Vernadsky was the rector of the Taurida University in Simferopol. 
and in the Iconostasis. This problem is connected to the elaboration of the conceptions of the noosphere-pneumatosphere. In regards to this, several questions remain unanswered: What is the world of noos-pneuma? What is the difference between our world experienced through the senses and the world which is opened to our intuitive knowledge, as was supposed by Plato and his followers? We can attempt to find answers to these questions through the works of both Vernadsky and Florensky.

\section{Noosphere and pneumatosphere}

Vernadsky's new idea of the noosphere ${ }^{8}$ was one particularly admired by Florensky. In his letter from 21 September 1929, Florensky suggested the concept of "pneumatosphere", which refers to the transformation of matter through spirit, while Vernadsky focused more on mind and matter:

...the thought of the existence in the biosphere or, perhaps, above the biosphere of what might be called the pneumatosphere, that is of the existence of a particular part of matter involved in the cycle to life in a general sense is hardly open to doubt. But there is much data, not yet sufficiently studied, it is true, that would seem to indicate a special kind of durability in material formations permeated through by the spirit such as works of art. This makes one suspect the existence of a corresponding particular sphere of matter in the cosmos. At present it is premature to speak of the pneumosphere as a field for scholarly research. Possibly, the question should not have been touched on at all in writing. Only the impossibility of talking to you personally has induced me to air the thought in a letter [13, p. 121 $]^{9}$.

Florensky wanted to express the indivisibility of matter and spirit, how the spiritual man is important for the transformation of the biosphere. Pyman clearly describes Florensky's philosophy of the environment as follows:

To master is to control, and we control what we have understood, 'named', 'grasped' and made our own. The world is a projection of our spirit and of the body to which the spirit is so intimately connected. Adam lost his God-given mastery of the world when he lost control himself, bringing division. But even in his fallen state man has not lost the magical power to control the world through the theurgy of religious (ascetic) effort, which involves first re-establishing control over the microcosmos of the body. For the body is our threshold of awareness, more important by far than the materialists and positivists on the one hand, or the spiritists on the other, care to think: 'mathematics, astronomy, physics, etc. etc. not to mention art, are luminous reflections of spirit ilumining, ordering, organising, assimilating and revivifying the albeit sin-shattered body' $[13, \text { p. 120 }]^{10}$.

Florensky's anger and frustration emanate from his letter to Anna written on 1011 March 1936:

My lifework is destroyed and I will never be able or willing to take up again the labour of fifty years. I will not want to, because I was not working for myself or my own advantage and, if humanity, for whose sake I never knew a personal life, has considered it possible to completely annihilate all that was done for its sake and only awaited the last finishing touch-

8 About the evolution of the concepts of biosphere-noosphere in Vernadsky's thought see [17, p. 82-89].

9 The letter was first published only in 1984.

10 The letter was first published only in 1984 [13, p. 121]. 
es, then all the worse for humanity, let them try to reconstruct what they have destroyed for themselves $\langle\ldots\rangle$. I know enough of history and the historical development of thought to foresee the time when people will begin to gather up the pieces of what has been destroyed. But that does not as much comfort me as it does exasperate me: detestable human stupidity, spun out from the beginning of history and, no doubt, intent on continuing to the end. But that's enough - all this about myself is really uninteresting... [13, p. 177].

In the article "Pavel Florenskij. Matematica e visione del mondo" [Pavel Florensky. Mathematics and Vision of the World], Renato Betti, a professor of geometry at the Politecnico di Milano, dealt with the importance of mathematics in the process of knowing the spiritual world of Truth, which we can find in Florensky's work. Like Plato, Florensky was convinced that mathematics was the way to the world of the Truth, which exists in our world merely in a fragmented form. The goal of humanity was to unite the single pieces of the Truth, and such should also be the main goal of science. But this work requires a holistic view of the world, which Florensky recognized in Vernadsky. They both knew how important mathematics was for knowledge and they both asked about what was real.

In a letter to Kirill from Solovki in 1936, Florensky wanted to share with Vernadsky his reflections about the problem of the symmetry - asymmetry of living matter. Pyman wrote:

On 3 April, Florensky directed a letter through Kirill to his teacher, Academician Vernadsky, in which he overcomes his anger at 'human stupidity' and tries to reformulate the cornerstone of his philosophy: the reality of time and space. Thought of by rationalists as an abstract way of organising our perceptions and by the sensualists as subjective delusion, for Florensky space and time are the key to understanding and, the most weighty proof of the reality of space-time is the fact of the existence of asymmetry in nature and of irreversibility in the temporal... Asymmetry in time is irreversibility. To be is to be in time, to be in time is to be irreversible, that is 'historical' [13, p. 177].

However, as Florensky wrote to his mother in 1900, the key to a world view was mathematics [13, p. 27].

The topic of asymmetry was important for both Florensky and Vernadsky, as was the question of how to express the opposite meaning of symmetry. In a letter from 12-13 October 1936, Florensky explained to Kirill why he preferred to use the word asymmetry rather than assymmetry or dissymmetry: "In former times I began to write about asymmetry (it is necessary to write asymmetry, $\dot{\alpha}-\sigma \nu \mu \mu \varepsilon \tau \rho i \alpha$, and not the French assymmetry in relation to azymetry). I agree with V.I.that the term asymmetry is not exact, but I do not like dissymetry as a word composed from Latin dis and Greek $\sigma \nu \mu \mu \varepsilon \tau \rho i a^{\prime \prime}[14$, p. 570-571].

On the contrary, Vernadsky used the terms asymmetry - dissymmetry in a specific sense: asymmetry as an abstract opposition to symmetry in the case of inert matter like crystals, and dissymmetry in the case of living matter. The problem of asymmetry - dissymmetry was treated by Vernadsky in the book The Chemical Structure of the Earth's Biosphere and Its Surroundings, which he began to write in the 1940s and considered the summary of his life's work.

In The Chemical Structure Vernadsky used the term dissymmetry mainly because it was connected to the structure of a molecule in living matter; he explained that the term asymmetry as an absence of symmetry did not exist in reality and was used only in rela- 
tion to inert matter. Then again, in his Scientific Thought as a Planetary Phenomenon he pointed out that asymmetry was used instead of the term dissymmetry, which was confusing for scientists ${ }^{11}$. Finally, in one of the notes included in the aforementioned book, he stated the following: "the principle of dissymmetry has been formulated by P.Curie (1859-1906), but has been well and intuitively understood and expressed by L. Pasteur" $[18$, p. 34].

Pasteur discovered dissymmetry of the organic molecules in living beings, which is different from the symmetrical geometry of crystal in non-living matter. Vernadsky postulated that there were three forms of geometry which correspond to geometrical properties of the space we live in: Euclidean, Lobachevskian, and Riemannian [18, p.35]. In his view, this dissymmetry of molecules in living matter was subordinate to Riemannian's geometry and not Euclidean [19, p. 188]. However, inert matter is part of the biosphere and Florensky recognized his research on compenetration and integration of inert and living matters as an important part of Vernadsky's work.

Living matter and life is reality, which Vernadsky divided into three parts:

1) The reality of human life.

2) The microscopic reality of the atomic phenomena.

3) The reality of outer space.

Regarding the reality of space, Vernadsky explained when and why he used the term "reality", and how it differed from "cosmos" and "nature". In Nauchnaya mysl' kak planetnoe yavlenie, Vernadsky distinguished between reality, cosmos, and nature. $\mathrm{He}$ preferred to use the term "reality" because "the concept of nature is, if we take it in a historical aspect, a complex one. It very often covers only the biosphere, and it is more convenient to use it in this sense or even not to use it at all $\langle\ldots\rangle$. Historically, this will correspond to the vast majority of uses of this concept in natural science and in literature. The concept of "cosmos" may be more convenient to apply only to the part of reality covered by science, and in this case a philosophically pluralistic idea of reality is possible, where there will not be a single criterion for cosmos" [11, p. 243 $]^{12}$. Vernadsky recognized that there was no contradiction between scientific views and philosophical and religious constructions about the cosmos. On 13 October 1929 he wrote to Florensky: "I think we are experiencing very crucial turning point in the scientific worldview. For the first time the phenomena of life should enter in the scientific worldview and maybe we arrive to weakening of the contradiction that is observed between scientific ideas about the Cosmos and its philosophical or religious construction. Indeed, now

11 "Strangely enough, this word had been written down, especially in German literature, by the word "asymmetry". But asymmetry corresponds to an absence of symmetry (in homogeneous structures, it corresponds to the hemihedria of a triclinic system). This nomenclature evidently ought to be abolished for it confuses the scientist. However our special literature still uses it, after the Germans" [18, p. 210].

12 Even though I have already referred to the English translation of the book Nauchnaia mysl' kak planetnoe iavlenie (Scientific Thought as a Planetary Phenomenon), in this case I prefer to translate this passage by myself to preserve the concept of cosmos (translated in the English version as space) because it has a precise meaning in Russian religious philosophy. Berdyaev explained the difference between this given world of necessity and cosmos in the book The Meaning of the Creative Act: "'This world' is not the cosmos; it is a non-cosmic condition of divisions and enmity, the atomization and falling apart of the living monads of the cosmic hierarchy. And the true way is that of spiritual liberation from 'the world', the liberation of man's spirit from its bondage to necessity $<\ldots>$. The cosmos is true being, but the 'given world' is a phantom and so is the necessity of the given world" [20, p. 11]. 
everything that is dear to humanity is not found in it - in a scientific view of Cosmosspace" [16, p. 27].

When Vernadsky and Florensky write about transformation of the biosphere in the noosphere-pneumatosphere, they mean a transformation of reality, but they speak about reality in different ways: Vernadsky as a scientist, Florensky more as a priest. In Florensky's view, reality is a world of the Truth as he described in his book The Pillar and Ground of the Truth. Even if the idea of the Truth is similar to Plato's idea of the Truth, Florensky, as well as Russian religious philosophers, did not want the two worlds - world of ideas and world of phenomena - to remain separate. Russian religious philosophers strived for the unification of the given world of necessity with the world of "true being", which is also called a world of Sophia, the perfect creation of God or perfect humanity which actual human beings should achieve. But this unification has to be total and has to comprehend not only man but also nature.

The two concepts of the noosphere and the pneumatosphere and the similarities between them can bring us to the main topics of Russian religious philosophers, who emphasized intuition as a tool of knowledge because they were both convinced that the biosphere is transforming to the noosphere or pneumatosphere, which means that intellectual or spiritual activity of man determined this transformation.

Florensky was one of the main protagonists of Russian philosophy, who found his predecessor in "the first professional Russian philosopher" Vladimir Solovyov. Both Solovyov and Florensky believed in the harmonical evolution of nature in Beauty. They used the term Beauty in the same sense as Plato, but contrary to Plato the Russian religious philosophers wanted to unify the ideal Beauty with the realistic material world. In Solovyov's view, "we should define beauty as the transformation of matter through the embodiment in it of another, supra-material principle" [21, p. 36]. But man cannot help the natural evolution of nature in the Beauty if he is unable to contemplate the "world of ideas", which is possible through the activity of nous or intellectual intuition. Intuition is an important part of knowledge for Russian religious philosophers, who were influenced by Slavophiles.

Among important Slavophiles was also Kireevsky, who interpreted faith as intuition which allows one to see Truth [22]. However, reason can experience intuitive vision only at a high stage of moral development. In Kireevsky's view, faith is not trust in external authority, but "a living and whole vision of the mind" [23, p. 21]. Mochulsky was convinced that "Solov"ëv absorbed entirely Kireevsky's world-view" [24, p. xvii].

Solovyov was also convinced that a man has to achieve a radical transformation of himself, and for this purpose he wrote the Justification of the Good, which "remains even today the single most comprehensive and systematic ethical treatise in the Russian language" [25]. Florensky continued Solovyov's work, especially in The Pillar and Ground of the Truth. The ideas of Beauty, Good, and Truth are Plato's highest ideas, which are treated by Solovyov and Florensky in their work for the purpose of their implementation in this world.

In the Fourth Letter of The Pillar and Ground of the Truth, Florensky explained that the metaphysical ideas of Truth, Good, and Beauty were not separated, but they constituted one principle, which could be observed from different angles: "Spiritual life as emanating from "I," as having its center in "I," is the Truth. Perceived as the immediate action of another, it is Good. Objectively contemplated by a third, as radiating outward, it is Beauty" [15, p. 56]. 
Florensky also emphasised that symmetry was not the main reason why Beauty was created, but also dissymmetrical colours were beautiful. The main cause of Beauty, however, was light. Florensky uses the word light also as an expression of Spirit, as it is expressed in Letter Four, which is identified by the title "The Light of the Truth." Symbolically, light corresponds to the Truth $[15, \mathrm{p} .70]$.

Although Vernadsky was a scientist, he maintained contact with Russian idealists, admired Florensky, and appreciated The Pillar and Ground of the Truth. Despite this, Vernadsky did not write about Beauty; he focused on scientific truths, particularly in the third section of Scientific Thought as a Planetary Phenomenon. He intended to remain at the level of science which does not "deal with absolute truths but with the unquestionably exact logical conclusions and with relative assertions whose correctness varies within definite limits" [18, p. 153].

It is interesting to note that Vernadsky used the plural in the case of "absolute truths", but he knew well from the Florensky's writings that absolute Truth-istina, as interpreted by Russian religious philosophers, could be only one, so the expression "absolute truths" is a contradiction; he wants to show there cannot be an absolute Truth in science because the Truth is part of a metaphysical word, which cannot be examined by human rationality. In Florensky's view "Truth is intuition that is provable, i. e., discursive" and "it is the unity of opposites, coincidentia oppositorum" [15, p.33].

Vernadsky wanted to unify science and also scientific terminology, as we saw in the case of asymmetry - dissymetry, to create a scientific center ${ }^{13}$, and separate scientific thought from the religious and philosophical influences because they "do not have such compulsory nature" [18, p. 123]. Development of scientific thought is very important for the transformation of biosphere to noosphere because "science is the real decisive factor in the noosphere" [18, p. 131].

Florensky's idea of pneumatosphere was a more metaphysical one connected to the activity of spirit-pneuma. He was very precise in his terminology because he considered the word as energy which connects a person with reality overpassing his subjectivity. But as he expressed in his letter, he was convinced that "at present it is premature to speak of the pneumatosphere as a field for scholarly research" [13, p. 121]. Perhaps this was why he continued to transmit his knowledge to Vernadsky only at the scientific level, as we can see from the letters to his son Kirill.

In conclusion, through the example of Vernadsky's and Florensky's scientific and philosophical interaction we can see that science was not harmed by religious and spiritual ideas expressed by Florensky. Religion and science can work together if religious beliefs are based on critical thinking and scientific knowledge, which is evidenced by the example of Florensky's work. Even though Vernadsky recognized Florensky's ideas, he became famous as an exceptional scientist, who continued to spread science during the oppressive Soviet period. But in the end, Vernadsky's scientific evolution was completed in the conception of the noosphere, which unifies science, faith, and philosophy. Nowadays, the question of the evolution of the biosphere in the noosphere is overshadowed by the

13 On 7 March 1925, in a letter to the Czech mineralogist professor F. Slavik, Vernadsky wrote: "I am deeply confident of the great future - not far off — of biogeochemical research work for practical life and for the development of human thought, for the success of other sciences, in particular biology, geology, chemistry, and mineralogy. This development is impossible without the creation of a scientific center. There is no such center now" [4, p. 189]. 
problem of the Anthropocene, which is still unresolved. The concept of the noosphere was to be an evolutionary theory of the harmonic development of the biosphere, but today the Anthropocene epoch points to the destructive behaviour of man, who needs new ethics. We may suppose that the ethics of Russian religious philosophers with a holistic tendency to the unification of the world can be helpful. In the case of Vernadsky and Florensky, ethical behaviour rooted in Russian religious philosophy brought a positive result, which showed the way to wholeness and unification of the world.

\section{References}

1. Edmunds, W. M. and Bogush, A. A. (2012), Geochemistry of natural waters - The legacy of V.I. Vernadsky and his students, Applied Geochemistry, vol. 27, pp. 1871-1886.

2. Hamilton, C. and Grinevald, J. (2015), Was the Anthropocene anticipated?, The Anthropocene Review, vol. 2 (1), pp. 59-72.

3. Rosenthal, B. G. (ed.) (1997), The Occult in Russian and Soviet Culture, Ithaca: Cornell University Press.

4. Bailes, K. E. (1990), Science and Russian Culture in an Age of Revolutions. V.I. Vernadsky and His Scientific School, 1863-1945, Bloomington: Indiana University Press.

5. Young, G. M. (2012), The Russian Cosmists. The Esoteric Futurism of Nikolai Fedorov and his Followers, New York: Oxford University Press.

6. Obolevitch, T. (2019), Faith and Science in Russian Religious Thought, Oxford: Oxford University Press.

7. Vernadsky, V. I. (2005), Some Words About the Noösphere, transl. by Vernadsky, G., $21^{\text {st }}$ Century Science and Technology, vol. 18 (1), pp. 16-21.

8. Samson, P. R. and Pitt, D. (eds) (1999), The Biosphere and Noosphere Reader. Global environment, society and change, London and New York: Routledge Publ.

9. Nemeth, T. (2017), Kant in Imperial Russia, Dordrecht: Springer. (Studies in German Idealism, vol. 19).

10. Osipov, I.D. (2018), Russian constitutionalism considered in the historical and philosophical perspectives, Filosofskii polilog: Zhurnal Mezhdunarodnogo tsentra izucheniia russkoi filosofi, vol. 1 (3), pp. 131-140. (In Russian)

11. Vernadsky, V.I. (2004), The Biosphere and Noosphere, Moscow: Airis-press Publ. (In Russian)

12. Mikulinsky, S. R. (1984), George Sarton and Vladimir Ivanovich Vernadsky, Isis, vol. 75 (1), pp. 56-62.

13. Pyman, A. (2010), Pavel Florensky: A Quiet Genius. The Tragic and Extraordinary Life of Russia's Unknown Da Vinci, New York: Continuum.

14. Florensky, P. A. (1998), Letters from the Far East and Solovki, Sochineniia, in 4 vols., vol. 4, Moscow: Mysl' Publ. (In Russian)

15. Florensky, P. (2004), The Pillar and Ground of the Truth. An Essay in Orthodox Theodicy in Twelve Letters, Princeton and Oxford: Princeton University Press.

16. Berestovskaya, D.S. (2013), V.I. Vernadsky and P.A.Florensky - the Fates of Russian Thinkers, Uchenye zapiski TNU im. V.I. Vernadskogo. Seriia: Filosofiia. Kul'turologiia. Politologiia. Sotsiologiia, vol. 24 (65), no. 3, pp. 17-30. (In Russian)

17. Naldoniová, L. (2013), The Transition from the Biosphere to the Noosphere in Vladimir Vernadsky's view, in Škabraha, M. (ed.), Limity vědeckého poznání, Ostrava: Philosophical Department of Ostrava University, pp. 81-92.

18. Vernadsky, V.I. (1997), Scientific Thought as a Planetary Phenomenon, transl. by Starostin, B. A., Moscow: Nongovernmental Ecological V.I. Vernadsky Foundation Publ.

19. Vernadsky, V.I. (1987), The Chemical Structure of the Earth's Biosphere and Its Surroundings, Moscow: Nauka Publ. (In Russian)

20. Berdyaev, N. (1962), The Meaning of the Creative Act, transl. by Lowrie, D. A., New York: Collier Books.

21. Soloviev, V.S. (2003), The Heart of Reality: Essays on Beauty, Love and Ethics, ed. and transl. by Wozniuk, V., Notre Dame: University of Notre Dame.

22. Li, H. (2018), Reunion with God: Comparing and Contrasting Kireyevsky's and Solovyov's Philosophical and Religious Thoughts, Filosofskii polilog: Zhurnal Mezhdunarodnogo tsentra izucheniia russkoi filosofii, vol. 1 (3), pp. 47-59.

23. Lossky, N. O. (1952), History of Russian Philosophy, London: George Allen \& Unwin.

24. Nemeth, T. (2014), The Early Solovêvv and His Quest for Metaphysics, Basel: Springer International Publishing. 
25. Solovyov, V. (2005), The Justification of the Good: An Essay on Moral Philosophy, transl. by Duddington, N. A., New York: William B. Eerdmans Publishing.

Author's information:

Lenka Naldoniová - Dr. Phil., Assistant Professor; lenka.naldoniova@osu.cz

\section{Философское и научное взаимодействие В. И. Вернадского и П. А. Флоренского}

\section{Л.Налдониева}

Остравский университет,

Чешская Республика, 701 03, Острава, ул. Дворакова, 7

Для цитирования: Naldoniová L. Philosophical and scientific interaction between Vladimir Vernadsky and Pavel Florensky // Вестник Санкт-Петербургского университета. Философия и конфликтология. 2020. Т. 36. Вып. 4. С. 645-656. https://doi.org/10.21638/spbu17.2020.404

Статья посвящена анализу философско-научного диалога между Владимиром Вернадским и Павлом Флоренским в контексте русской философии. Флоренский сформулировал свою религиозную философию в книге «Столп и утверждение Истины», оказав большое влияние на Вернадского. Два философа обменивались мыслями посредством писем: во время своего тюремного заключения Флоренский писал письма на научные темы своему сыну Кириллу, который работал с Вернадским. Кирилл Флоренский стал точкой соприкосновения двух мыслителей и продолжателем творчества Вернадского. Цель статьи - показать взаимодополняемость работ Вернадского и Флоренского с особым упором на их концепцию ноосферы-пневматосферы, связанную с метафизикой Платона, которую Флоренский интерпретировал как слово Истины или абсолютной реальности. Посредством изучения писем и дневников Вернадского и Флоренского и сопоставления их представлений о ноосфере и пневматосфере, а также интерпретации действительности в их трудах мы можем обнаружить влияние важных для русских религиозных философов концепций, таких как стремление к целостности и интуиции. В первой части статьи рассмотрены взгляды Вернадского на русских идеалистов, вторая часть посвящена отношениям Вернадского и Флоренского, а третья - понятиям ноосферы, пневматосферы и концепции реальности (живого существа) - абсолютной реальности (Истины). Тем самым обосновывается тезис о взаимодополняемости интерпретаций Вернадского и Флоренского, которые не противоречат друг другу, потому что, хотя Вернадский имел дело с реальностью Земли и ее эволюцией, а Флоренский сосредоточился на метафизическом мире, оба исходили из понимания эволюции биосферы-ноосферы / пневматосферы через деятельность человека. Статья является первым исследованием на английском языке, сфокусированным на научном и религиозно-философском взаимодействии между Вернадским и Флоренским.

Ключевые слова: В.И. Вернадский, П.А.Флоренский, ноосфера, пневматосфера, русская философия, асимметрия, диссимметрия, живая материя, реальность, интуитивное знание, истина, цельность.

Статья поступила в редакцию 19 декабря 2019 г.; рекомендована в печать 23 сентября 2020 г.

Контактная информация:

Налдониева Ленка - канд. филос. наук, доц.; lenka.naldoniova@osu.cz

* Статья опубликована по результатам исследования, финансируемого факультетом искусств Остравского университета, проект SGS03/FF/2019-2020 «Bílá místa dějin a současnosti filozofie: Osobnosti a témata na okraji kánonu». 